DOI 10.31558/2519-2949.2021.1.12

УДК 323:159.923.2:303.094.4:316.32

ORCID ID: orcid.org/0000-0001-7283-3528

Польовий М. А., Донецький національний університет імені Василя Стуса

\title{
СПІВВІДНОШЕННЯ КОГНІТИВНОГО ПІДХОДУ ТА ЗАСАД ДЕРЖАВНОЇ ПОЛТТИКИ ЩОДО НАЦІОНАЛЬНОЇ УДЕНТИЧНОСТІ (НА ПРИКЛАДІ СРСР І ДЕРЖАВИ ІЗРАЇЛЬ)
}

\begin{abstract}
Статтю присвячено аналізові змісту когнітивного підходу до трактування начіональної ідентичності та визначено особливості втілення прикладних висновків з иього підходу до формування національної політики в колишньому СРСР та у сучасній Державі Ізраїль. Не зважаючи на різні масштаби цих держав підставою для співставлення постає надзвичайна національна або начіонально-релігійна строкатість їх населення та життєва важливість врахування національно-релігійних чинників у державній політиці. В статті окреслено основні підходи до розуміння націоналізм та визначено певні переваги у цьому, які надає когнітивний підхід. Визначено, ще когнітивний підхід переключається на «формуючі» та «групуючі» види діяльності, зокрема класифікацію, категоризачію й ідентифікачію та конщентрується, значною мірою, на світосприйнятті простих людей. Окреслено ключові поняття при визначенні природи соціальної ідентичності. До них віднесено «соиіальну категоризацію», щз постає інструментом сегментації, класифікаиії і впорядкування соиіального середовища, "соиіальне порівняння», щฺо постає прочесом забезпечення міжсрупової диференщіації через співставлення ознак, щэ характерні ін-групі й аутгрупі, та «соиіальну ідентифікацію», що постає результатом соиіального порівняння та обумовлюється сочіальними категоріями, до яких відносяться індивіди. Зроблено висновок, що як в СРСР, так і в Державі Ізраїль основою для ідентифікачії та самоідентифікачї̈ виступає класифікація $і$ категоризачія. Вони використовуються для розподілу престиюсних робочих місиь $i$ соціальних позицій, доступу до вищої і престижної середньої освіти тощо. Однак зауважено, щуо в основі ици держсавних класифікацій $і$ категоризаџій лежать різні підстави - етнічна та територіальна національність у випадку державної наиіональної політики в СРСР, та релігійноконфесійна приналежність (дещฺо міксована лінгвістичними та (квазі)етнічними характеристиками) у випадку політики Держави Ізраїль.

Ключові слова: державна начіональна політика, начоінальна ідентифікаиія, СРСР. Держава Ізраїль, когнітивний підхід
\end{abstract}

Як відомо, в основі численних класифікацій теорій нації і націоналізму лежать різні підстави, проте найбільш поширеною залишається двохелементна або трьохелементна (в якій третій елемент фактично проміжний). Найчастіше говорять про модерністські / конструктивістські / інструменталістські / ситуативістські теорії з одного боку, примордіалістські / есенціалістські / перенніалістські теорії - з іншого, та етносимволізм, який нібито їх врівноважує [7].

I все ж, на наш погляд, ця класифікація не здатна вмістити всі дослідницькі підходи до проблем нації і націоналізму, передусім так звані постмодерністські, що хоч і зародились всередині модерністського напрямку, якісно відмінні від нього. Серед постмодерністських підходів можна виділити, зокрема, феміністський (С. Уолбі [10], Г. Слуга [19]), постколоніальний (П. Чаттерджі [12]), постнаціональний (Ю. Габермас [11]), дискурсивний (К. Калхун [6], К. Вердері [4]) дослідження «банальних» націоналістичних практик (М. Білліг [15]), нарешті, когнітивний підхід (Р. Брубейкер [2; 3]).

Як зазначає британський дослідник націоналізму Дж. Бройі, основні труднощі, що перешкоджають чіткому визначенню терміну «націоналізм», полягають у тому, що різні дослідники розуміють під цим терміном доволі різні речі, у першому наближенні: доктрину, політику або почуття. Водночас всі ці підходи мають певні обмеження і жоден з них не може витіснити собою інші [1, с. 201-204].

У цьому напрямку розмірковує й інший знаменитий британський дослідник націоналізму Е. Хобсбаум. Він пропонує починати аналіз «національного питання» 3 доктрини націоналізму, 3 того 
як націоналісти уявляють собі «націю», але водночас визнає важливість вивчення й так званих національних почуттів [16, с. 5-11]. На його думку, в основі націотворення лежить передусім конструювання зверху, проте націоналізм не можна збагнути без його сприйняття знизу, «з точки зору забобонів, надій, потреб, сподівань і інтересів простої людини які необов'язково є національними, а ще меншою мірою націоналістичними» [16, с. 10].

Теорія «маніпуляції еліт» вважає націоналізм результатом маніпулювання зверху, з боку безпринципних еліт, які підбурюють національні емоції і почуття простих людей, що стають в процесі заручниками інтересів істеблішменту. Але розуміння націоналізму виключно у такий, вузько інструментальний спосіб, на нашу думку, є помилкою. В основі націоналізму слід бачити й інші, психологічні установки, що впливають на соціальну уяву простих людей, i через це - на політичний процес. Врешті-решт, це бачення дозволяє переформулювати позиції «примордіалістів» i «інструменталістів» як взаємодоповнюючі, спрямовані на розгляд різних питань: на те, як мисляться групи, й на те, як вони використовуються на практиці.

Саме на переживаннях простих людей, значною мірою, і концентрується когнітивний підхід. Він, за визначенням Р. Брубейкера, відходить від субстанциалістського розуміння соціального світу (як сукупності расових, етнічних і національних груп) i переключається на «формуючі» та «групуючі» види діяльності, зокрема класифікацію, категоризацію й ідентифікацію [3, с. 152-165].

Британські соціальні психологи Г. Теджфел і Дж. Тернер, до яких, значною мірою, апелює Р. Брубейкер, основним критерієм для членства в соціальній групі називають ідентифікацію та самоідентифікацію індивідів. Саму ж соціальну групу вони мислять як сукупність індивідів, які відносять себе до однієї соціальної категорії, поділяють схожі емоції та ставлення до неї та навіть до самого факту (само)визначення у такий спосіб.

Для розкриття природи соціальної ідентичності Г. Теджфел і Дж. Тернер вводять три ключові поняття:

- «соціальна категоризація», що постає інструментом сегментації, класифікації і впорядкування соціального середовища;

- «соціальне порівняння», що постає процесом забезпечення міжгрупової диференціації через співставлення ознак, що нібито характерні ін-групі й аут-групі;

- «соціальна ідентифікація», що постає результатом соціального порівняння та обумовлюється соціальними категоріями до яких індивіди відносяться.

Нарешті Дж. Тернер перевертає причинно-наслідковий зв'язок між ідентичністю та міжгруповою поведінкою. Міжгрупові процеси стають безпосереднім результатом соціальної категоризації, точніше самокатегоризації, а не навпаки [9].

Отже, як зазначає Р. Брубейкер, в останні роки «групуючі» види діяльності стали основним предметом дослідження при вивченні проблем етнічності, раси та національності. Коли конструктивістські установки отримали визнання та поширення в науковому світі, об'єктивістське розуміння етнічності, раси та національності було витіснено суб'єктивістськими підходами, в яких етнічність, раса та національність визначаються не в термінах об'єктивно існуючих спільнот, а в термінах вірувань та (само)сприйняття їх учасників [3, с. 127-128].

У цьому контексті Р. Брубейкер розглядає квазі-фрейдістську теорію «повернення придушеного», яка претендує на пояснення існуючих наразі у Східній Свропі національних ідентичностей та національних конфліктів. Вони нібито були глибоко вкорінені в докомуністичну історію Східної Європи і з падінням антинаціональних комуністичних режимів, що жорстко придушували ці ідентичності та конфлікти, останні поновились 3 новою силою.

Звісно комуністичні режими Східної Свропи та Радянського Союзу придушували націоналізм, але робили вони це у інший спосіб, ніж це стверджує теорія «повернення придушеного». Ця теорія стверджує, що комуністичні режими у Східній Європі придушували не тільки націоналізм, але й національність, але це глибоко помилкова думка, яку можна спростувати на прикладі Радянського Союзу.

Значною мірою, нації та націоналізм на сучасному пострадянському просторі розквітають сьогодні завдяки радянському режиму, що хоч і був антинаціоналістичним, ніколи не був антинаціональним, у тому сенсі, що він ніколи не придушував територіальну та етнічну національність, і навіть більше, намагався повсюди інституціоналізувати іiі. У такий спосіб комуністичний режим створив політичне поле, що потенційно та фактично сприяло розквіту націоналізму.

Радянський режим нарізав територію країни на більш ніж 50 національних територій, кожна 3 яких була визначена як батьківщина для конкретної етнонаціональної групи. Території найвищого 
рівня - радянські республіки, ті, які наразі $є$ незалежними державами, були визначені як квазінаціональні держави, що мали власну назву, територію, конституцію, законодавчі збори та адміністративний апарат, культурні та наукові установи тощо.

Водночас радянський режим розділив всіх громадян згідно вичерпної системи етнічних національностей, що виключають одна одну. Відповідно до державної системи класифікації, етнічна національність була не тільки статистичною категорією, але i, що більш важливо, означала обов'язковий і приписуваний статус, який держава давала людині на підставі його походження. Цей статус був зареєстрований в особистих документах і майже в усіх офіційних паперах, анкетах і т.п. Він використовувався для розподілу престижних робочих місць і соціальних позицій, обмежуючи можливості для одних національностей, передусім євреїв, і гарантуючи доступ до них іншим зокрема так званим титульним національностям в їх «власних» республіках.

У такий спосіб територіальна та етнічна національність в Радянському Союзі була повсюдно закріплена як соціальна та культурна форма, що, врешті-решт, набула фундаментальний для людських почуттів характер.

Національність мала розроблену систему соціальної класифікації, яка включала до себе стандартизовану систему соціальної бухгалтерії, набір маркерів для проведення міжгрупових кордонів, легітимні форми колективних і особистих ідентичностей тощо. I коли суспільний простір різко розширився, ці повсюдно інституціалізовані форми були з легкістю політизовані. Врешті-решт, вони визначили когнітивні рамки за якими пішла політична дія, що перетворила колапс режиму в дезінтеграцію держави та продовжує формувати політичну свідомість на пострадянському просторі [2, с. 81-84].

Отже, не слід забувати, що класифікація і категоризація, які нав'язуються владними інститутами (i іншими політичними акторами), самі впливають на ідентифікацію, суспільну організацію і різноманітні (зокрема політичні) вимоги громадян. До того ж, офіційно визнані ідентичності в таких країнах як нацистська Німеччина, ПАР часів апартеїду, Радянський Союз, нарешті, Держава Ізраїль $€$ не тільки статистичними категоріями, а й політико-правовими [3, с. 131-134].

На відміну від «західних» ліберально-демократичних країн, в Ізраїлі ще з часів Британського Мандата на Палестину і навіть раніше базовою характеристикою відмінності визнається не етнічна, а релігійно-конфесійна приналежність, яка, накладаючись на етнічну спільноту, здатна ії підсилювати, а розколюючи - послаблювати [5]. До того ж ця базова характеристика відмінності доповнюється лінгвістичною та (квазі)етнічною, що, на нашу думку, $є$ одним 3 найважливіших механізмів ізраїльської «політики визнання».

Сіоністське керівництво розділяє всіх громадян (і резидентів країни) відповідно до вичерпної системи категорій, які виключають одна одну. Відповідно до державної системи класифікації, персональний статус $\epsilon$ не тільки статистичною категорією, але і підставою для розподілу престижних робочих місць і соціальних позицій, основою для доступу до вищої та престижної середньої освіти, нарешті, для служби в армії, яка в ізраїльських реаліях є скоріше правом, аніж обов'язком [13; 18].

Зауважимо, що сіонізм, як і будь-яка інша націоналістична ідеологія та практика, намагається більш-менш чітко визначити кордони «свого» національного колективу. Хоча суто теоретично націоналізм може поширюватись на весь світ і на все людство, саме партикулярне його розуміння наразі є загальноприйнятим і абсолютно домінує на практиці.

Намагаючись затушувати традиційні та природні для євреїв культурні та культурно-релігійні відмінності, сіоністська ідеологія визначає базовий національний колектив в Палестині/ЕрецІсраель через протиставлення конституйованому «Іншому», а саме палестинським арабам, в порівнянні з якими різні категорії євреїв мають відчути (і насправді відчувають) свою відносну спорідненість.

Держава Ізраїль твердо та послідовно протистоїть розмиванню базової національної ідентичності єврейської чи єврейсько-ізраїльської. В уяві ії державних, квазі-державних і державно-релігійних інститутів єврейство невіддільно від юдаїзму (насамперед ортодоксального й ультраортодоксального, але також реформістського та консервативного напрямків). «Сврейська держава» апріорі визнає юдеями всіх євреїв за Галахою (традиційним єврейським/юдейським правом), не приймаючи до уваги реальний рівень їх відданості єврейській релігійній традиції [8, с. 98-101].

Іншою категорією з позиції багатьох ізраїльських інститутів і служб (зокрема Центрального статистичного бюро Ізраїлю) $є$ ізраїльські араби, до яких зазвичай, хоч і з важливими застереженнями, відносять всіх мусульман (зокрема черкесів), арабів-християн (включно з вірменами) і навіть друзів (яких ще в 1962 р. Ізраїль визнав окремою від арабів національною меншиною) [17; 18]. 
Права і обов'язки різних сегментів арабського сектора не тільки суттєво відрізняються від вироблених для євреїв, але i помітно відрізняються між собою. Показовим $є$ порядок (не)проходження ізраїльськими арабами військової служби в Ізраїлі. Військова повинність поширюється на черкесів і друзів (громадян Ізраїлю), добровільно нести службу мають право бедуїни (які нібито мають слабку арабську та арабо-палестинську самосвідомість), а також апріорі не служать в ізраїльській армії араби-християни та араби-мусульмани [13; 18]. І в цьому контексті, «національна» політика Ізраїлю не стільки прояв чуйності до особливих потреб різних категорій ізраїльських арабів, скільки направлена на сегментацію та ослаблення арабського сектора маніпуляційна політика держави.

Нарешті, до категорії «інших» наразі відносять всіх, хто з точки зору «єврейської держави» не $\epsilon$ ані арабом, ані (повноцінним) євреєм. Мова йде про тих, кого Держава Ізраїль визначає християнами-неарабами (зокрема маронітів), бахаї і тих, хто не підпадає під традиційне (а отже і державне) визначення єврейства (переважно це члени сімей євреїв і негалахічні євреї, передусім 3 країн колишнього Радянського Союзу [18].

Державні інститути та служби, цілком підконтрольні єврейській громаді Ізраїлю, розглядають категорію «інших» (передусім членів сімей євреїв і негалахічних євреїв) як інтегральну частину розширеного єврейського колективу країни. Ізраїльський істеблішмент, стурбований кількісними демографічними показниками арабської меншини, вважає за необхідне інтегрувати всіх «репатріантів» не тільки в ізраїльське суспільство, але i в його національно-культурне ядро [14, с. 119-125].

Отже класифікація і категоризація, як в СРСР, так і в Державі Ізраїль - основа для ідентифікації та самоідентифікації. Вони використовуються для розподілу престижних робочих місць і соціальних позицій, доступу до вищої і престижної середньої освіти тощо. Однак в основі цих державних класифікацій і категоризацій лежать різні підстави - етнічна та територіальна національність з одного боку, та релігійно-конфесійна приналежність (дещо міксована лінгвістичними та (квазі)етнічними характеристиками) - 3 іншого.

\section{Бібліографічний список:}

1. Бройи Дж. Подходы к исследованию национализма Нации и национализм / Б. Андерсон, О. Бауэр, М. Хрох и др.; пер. с англ. и нем. Л. Е. Переяславцевой, М. С. Панина, М. Б. Гнедовского. М. : Праксис, 2002. C. $201-235$.

2. Брубейкер Р. Мифы и заблуждения в изучении национализма Мифы и заблуждения в изучении империи и национализма / Р. Брубейкер и др. М. : Новое издательство, 2010. С. 62 - 109.

3. Брубейкер Р. Этничность без групп : монография. М. : Изд. дом Высшей школы экономики, 2012. 408 с.

4. Вердери К. Куда идут «нация» и «национализм»? Нации и нащионализм / Б. Андерсон, О. Бауэр,

М. Хрох и др.; пер. с англ. и нем. Л. Е. Переяславцевой, М. С. Панина, М. Б. Гнедовского. М. : Праксис, 2002. C. $297-307$.

5. Израильское конституционное право Zev Farber : веб-сайт. URL: https://israel-law.com/ru/kpravo/ (дата звернення: 12.10.2020).

6. Calhoun C. Nationalism. Open University Press and University of Minnesota Press, 2001. 310 p.

7. Нехаев А. В. Теории наций и национализмов: проблема классификации Омский научный вестник. Сер. Общество. История. Современность. 2016. № 2. С. 36 - 46.

8. Равицки А. Религиозные и секулярные евреи в Израиле: культурная война Созидание еврейского будущого / под. ред. Б. Лайтмана и М. Брауна. М. : Мосты культуры; Иерусалим : Гешарим, 2001. C. $83-108$.

9. Сушков И. Р. Социально-психологическая теория Джона Тернера Психологический журнал. 1993. Т. 14. № 3. C. $115-126$.

10. Уолби С. Женщина и нация Нации и национализм / Б. Андерсон, О. Бауэр, М. Хрох и др.; пер. с англ. И нем. Л. Е. Переяславцевой, М. С. Панина, М. Б. Гнедовского. М. : Праксис, 2002. С. 308 - 331.

11. Хабермас Ю. Европейское национальное государство: его достижения и пределы. О прошлом и будущем суверенитета и гражданства Нации и нащионализм / Б. Андерсон, О. Бауэр, М. Хрох и др.; пер. С англ. и нем. Л. Е. Переяславцевой, М. С. Панина, М. Б. Гнедовского. М. : Праксис, 2002. C. $364-380$.

12. Чаттерджи П. Воображаемые сообщества: кто их воображает? Наиии и национализм / Б. Андерсон, О. Бауэр, М. Хрох и др.; пер. с англ. и нем. Л. Е. Переяславцевой, М. С. Панина, М. Б. Гнедовского. М. : Праксис, 2002. С. 283-296.

13. Чернин В. Этническая карта Израиля: история, проблемы и перспективы развития Хроники Иерусалима. 2010. URL: http://gazeta.rjews.net/chernin2.shtml

14. Яаков Х. Б. Еврейский вопрос в еврейском государстве. Опыт формирования национального характера современного демократического государства : монография. Иерусалим : Гешарим, 2015. 192 с. 
15. Billig M. Banal nationalism : monograph. London: SAGE Publications, 2002. 200 p.

16. Hobsbawm E. J. Nations and Nationalism since 1780. Program, Myth, Reality : monograph. Cambridge: Cambridge University Press, 1992. 206 p.

17. Israel's Independence Day 2019 / Central Bureau of Statistics. State of Israel. Jerusalem, 2017. 3 p.

18. McGahern U. Multicultural norms and strategies: Minority policy in an ethnocratic state Mediterranean Politics. 2010. 15(3). P. 415 - 433. URL: https://eprint.ncl.ac.uk/file_store/production/187595/ABBA7D7B-559940F8-993D-BD4A11A73A97.pdf (Last accessed: 12.10.2020).

19. Sluga, G. Identity, Gender and the History of European Nations and Nationalisms Nations and Nationalism. 1998. Vol. 4. № 1. P. $87-111$.

\section{References:}

1. Broji Dzh. Podhody k issledovaniju nacionalizma Nacii i nacionalizm / B. Anderson, O. Baujer, M. Hroh i dr.; per. s angl. i nem. L. E. Perejaslavcevoj, M. S. Panina, M. B. Gnedovskogo. M. : Praksis, 2002. S. 201 - 235.

2. Brubejker R. Mify i zabluzhdenija v izuchenii nacionalizma Mify i zabluzhdenija v izuchenii imperii i nacionalizma / R. Brubejker i dr. M. : Novoe izdatel'stvo, 2010. S. 62 - 109.

3. Brubejker R. Jetnichnost' bez grupp : monografija. M. : Izd. dom Vysshej shkoly jekonomiki, 2012. $408 \mathrm{~s}$.

4. Verderi K. Kuda idut «nacija» i «nacionalizm»? Nacii i nacionalizm / B. Anderson, O. Baujer, M. Hroh i dr.; per. s angl. i nem. L. E. Perejaslavcevoj, M. S. Panina, M. B. Gnedovskogo. M. : Praksis, 2002. S. 297 - 307.

5. Izrail'skoe konstitucionnoe pravo Zev Farber. URL: https://israel-law.com/ru/kpravo/ .

6. Calhoun C. Nationalism. Open University Press and University of Minnesota Press, 2001. 310 p.

7. Nehaev A. V. Teorii nacij i nacionalizmov: problema klassifikacii Omskij nauchnyj vestnik. Ser. Obshhestvo. Istorija. Sovremennost'. 2016. № 2. S. 36 - 46.

8. Ravicki A. Religioznye i sekuljarnye evrei v Izraile: kul'turnaja vojna Sozidanie evrejskogo budushhogo / pod. red. B. Lajtmana i M. Brauna. M. : Mosty kul'tury; Ierusalim : Gesharim, 2001. S. 83 - 108.

9. Sushkov I. R. Social'no-psihologicheskaja teorija Dzhona Ternera Psihologicheskij zhurnal. 1993. T. 14. № 3. C. $115-126$.

10. Uolbi S. Zhenshhina i nacija Nacii i nacionalizm / B. Anderson, O. Baujer, M. Hroh i dr.; per. s angl. i nem. L. E. Perejaslavcevoj, M. S. Panina, M. B. Gnedovskogo. M. : Praksis, 2002. S. 308 - 331.

11. Habermas Ju. Evropejskoe nacional'noe gosudarstvo: ego dostizhenija i predely. O proshlom i budushhem suvereniteta i grazhdanstva Nacii i nacionalizm / B. Anderson, O. Baujer, M. Hroh i dr.; per. s angl. i nem.

L. E. Perejaslavcevoj, M. S. Panina, M. B. Gnedovskogo. M. : Praksis, 2002. S. 364 - 380.

12. Chatterdzhi P. Voobrazhaemye soobshhestva: kto ih voobrazhaet? Nacii i nacionalizm / B. Anderson, O. Baujer, M. Hroh i dr.; per. s angl. i nem. L. E. Perejaslavcevoj, M. S. Panina, M. B. Gnedovskogo. M. : Praksis, 2002. S. 283-296.

13. Chernin V. Jetnicheskaja karta Izrailja: istorija, problemy i perspektivy razvitija Hroniki Ierusalima. 2010. URL: http://gazeta.rjews.net/chernin2.shtml

14. Jaakov H. B. Evrejskij vopros v evrejskom gosudarstve. Opyt formirovanija nacional'nogo haraktera sovremennogo demokraticheskogo gosudarstva : monografija. Ierusalim : Gesharim, 2015. $192 \mathrm{~s}$.

15. Billig M. Banal nationalism : monograph. London: SAGE Publications, 2002. 200 p.

16. Hobsbawm E. J. Nations and Nationalism since 1780. Program, Myth, Reality : monograph. Cambridge: Cambridge University Press, 1992. 206 p.

17. Israel's Independence Day 2019 / Central Bureau of Statistics. State of Israel. Jerusalem, 2017. 3 p.

17. McGahern U. Multicultural norms and strategies: Minority policy in an ethnocratic state Mediterranean Politics. 2010. 15(3). P. 415 - 433. URL: https://eprint.ncl.ac.uk/file_store/production/187595/ABBA7D7B-559940F8-993D-BD4A11A73A97.pdf (Last accessed: 12.10.2020).

19. Sluga, G. Identity, Gender and the History of European Nations and Nationalisms Nations and Nationalism. 1998. Vol. 4. № 1. P. $87-111$.

\section{Polovyi M. The Relationship Between the Cognitive Approach and Public Policy on National Identity Grounds (on the Example of the USSR and the State of Israel)}

The paper is devoted to the analysis of the content of the cognitive approach to the interpretation of national identity. The features of the implementation of applied conclusions from this approach to the formation of national policy in the former USSR and in the modern State of Israel are and identified. Despite the different scales of these states, the basis for comparison is the extraordinary national or national-religious diversity of their population and the vital importance of taking into account nationalreligious factors in public policy. The paper outlines the main approaches to understanding nationalism and identifies some of the advantages of this cognitive approach. It is determined that the cognitive approach switches to "formative" and "grouping" activities, in particular classification, categorization and identification, and focuses, to a large extent, on the worldview of ordinary people. The key concepts in determining the nature of social identity are outlined. These include "social categorization", which is a tool for segmentation, classification and ordering of the social environment, "social comparison", which is the 
process of intergroup differentiation by comparing the characteristics of in-group and out-group, and "social identification". which is the result of social comparison and is determined by the social categories to which individuals belong. It is concluded that in both the USSR and the State of Israel, the basis for identification and self-identification is classification and categorization. They are used for the distribution of prestigious jobs and social positions, access to higher and prestigious secondary education, and so on. However, it is noted that these state classifications and categorizations are based on different groundsethnic and territorial nationality in the case of state national policy in the USSR, and religious affiliation (somewhat mixed with linguistic and (quasi) ethnic characteristics) in the case of policy of the State of Israel.

Keywords: state national policy, national identification, USSR, State of Israel, cognitive approach 